Bull. Fac . Agric., Cairo Univ. , 69:325-339 (2018).

\title{
EFFECT OF N- FERTILIZATION RATES AND SMALL-FLOWER UMBRELLA, (CYPERUS DIFFORMIS, L.) COMPETITION ON BROADCAST-SEEDED RICE, (ORYZA SATIVA, L.) PRODUCTIVITY AND NUTRIENTS UPTAKE
}

\author{
(Received:1.10.2018)
}

\author{
By \\ I. E Soliman, M. E. Z. Kenapar and O. M. M. Mobarak \\ Weed Research Central Laboratory, Agriculture Research Center, Giza, Egypt
}

\begin{abstract}
Two field experiments were conducted at Gemmeiza Agric. Res. Station, Gharbia Governorte, Egypt, during 2015 and 2016 summer seasons. The objective of this work was to study the effect of nitrogen fertilizer rates and small-flower umbrella (Cyperus difformis L.) competition on broadcast rice productivity and nutrient uptake. Each experiment included eighteen treatments. (The combination of three nitrogen fertilizer rates 50,70 and $90 \mathrm{~kg} \mathrm{~N} f e d^{-1}$, and six of Cyperus difformis L. densities, i.e., zero, 10, 20, 40, 80 and 100 (naturally infestation) plant $\mathrm{m}^{-2}$ ). A split plot design, with four replications, was used. The results revealed that increasing nitrogen rates increased significantly the studied broadcast rice growth parameters, yield and its components, in both seasons. Where the application of 70 and $90 \mathrm{~kg} \mathrm{~N}$ fed $^{-1}$ increased grain yield by 11.45 and $18.91 \%$ in the first season and 12.92 and $18.92 \%$ in the second season, respectively, compared to the lowest nitrogen fertilizer rate. Also, increasing nitrogen fertilizer rates had significant effect on most of NPK \% of both broadcast rice and Cyperus difformis L. plants at 60 and 80 days after sowing. N, P and $\mathrm{K} \%$ decreased with growth in both broadcast rice and Cyperus difformis L. plants and were higher in Cyperus difformis L. than broadcast rice in N\% showing that Cyperus difformis L. plants is a major competitor of broadcast rice plants for $\mathrm{N}$ nutrient. Moreover, the addition of nitrogen fertilizer rates significant affected $\mathrm{N}, \mathrm{P}$ and $\mathrm{K} \%$, NPK uptake and protein\% in broadcast rice grain. Application of 70 and $90 \mathrm{~kg} \mathrm{~N}$ fed $^{-1}$ increased protein \% in grain broadcast rice by $9.54 \%$ and $11.23 \%$ respectively in the second season, compared to $50 \mathrm{~kg} \mathrm{~N} \mathrm{fed}^{-1}$. On the contrary, increasing Cyperus difformis L. density $\mathrm{m}^{-2}$ had an adverse effect on broadcast rice growth, yield and its components in both seasons. Increasing number of Cyperus difformis L. plants from 10 to $100 \mathrm{~m}^{-2}$ reduced the grain yield by 5.37 to $47.43 \%$ in the first season and 7.98 to $48.88 \%$, in the second season compared to Cyperus difformis L. free treatment. Positive significant effects were detected for Cyperus difformis $\mathrm{L}$. density $\mathrm{m}^{-2}$ on $\mathrm{N}, \mathrm{P}$ and $\mathrm{K} \%$ of both broadcast rice and Cyperus difformis L. plants at 60 and 80 days after sowing as well as broadcast rice grain contents of N, P and $\mathrm{K}$ and protein in both seasons. Increasing Cyperus difformis L. plants from 10 to $100 \mathrm{~m}^{-2}$ decreased grain protein $\%$ from 0.17 to $2.11 \%$ in the first season and 0.17 and $1.09 \%$ in the second season compared with Cyperus difformis L. free plots. The interaction between $90 \mathrm{~kg} \mathrm{~N}$ fertilization rate and zero Cyperus difformis $\mathrm{L}$. plant $\mathrm{m}^{-2}$ gave the highest broadcast rice grain yield (4.21 and 4.15 ton fed ${ }^{-1}$ ) compared with $50 \mathrm{~kg} \mathrm{~N}$ fertilization rate and 100 Cyperus difformis L. plant $\mathrm{m}^{-2}$ which gave (1.84 and 1.71 ton $\left.\mathrm{fed}^{-1}\right)$ in the first and second seasons, respectively. The main findings of this investigation indicate that Cyperus difformis L. weed should be controlled to avoid broadcast rice grain yield losses due to its competition through integration between nitrogen fertilization and weed control treatments to get the highest grain yield of broadcast rice.
\end{abstract}

Key words: $N$ - fertilization, small-flower umbrella Cyperus difformis, L. density, Broadcast- seeded rice (Oryza sativa, L.), Growth, yield and yield components.

\section{INTRODUCTION}

Rice (Oryza sativa L.) is one of the most important cereal summer crops in Egypt, and is considered as a daily popular diet. Raising rice productivity per unit land area is very essential issue to meet the consistent increased population 
demands. Improvement of rice production can be achieved through replacement of the traditional cultivated varieties by new highyielding ones as well as optimizing the cultural practices.

Fertilizers play an important role in increasing rice grain yield productivity. Nitrogen is an important limiting element for rice growth, and its lack causes yield reduction in each stage, (Haefel et al.,2006). The proper dose of $\mathrm{N}$ fertilizer is considered a key to high crop production. However, Singh et al. (2017) reported a clear increase in photosynthetic capacity, specific leaf area, leaf area index, leaf area ratio, biomass accumulation and relative growth rate due to $\mathrm{N}$ application in all studied weed species. The authors added that, compared to the rice crop, weeds had a higher leaf area, and showed more efficient biomass gain with increasing $\mathrm{N}$ input. Belder et al. (2005) showed that rice grain yield increased with increasing nitrogen amount. In addition, Revathi (2009) found that lower weed density and weed dry matter in direct planting system entailed lower $\mathrm{N}$ removal by weeds. Seema and Tohi (2010),found that increased $\mathrm{N}$ level from 75 to $100 \mathrm{~kg} / \mathrm{ha}$ had increased the grain yield of direct seeded aerobic rice significantly (5\%), though further increase in nitrogen dose $(125 \mathrm{~kg} / \mathrm{ha})$ increased the grain yield insignificantly. The authors added that dry matter accumulation by the plant also increased by the increment of nitrogen. Weed dry weight at 60 DAS seemed to increase gradually with $\mathrm{N}$ dose, increment without significant differences. The increased levels of $\mathrm{N}$ increased the nutrient uptake by weeds at 60 DAS, but this increase was statistically insignificant in case of $\mathrm{N}$ and $\mathrm{P}$, and significant in case of $\mathrm{K}$ uptake. El-Dalil et al. (2017) reported that rice grain yield and all yield components were significantly affected due to the adopted $\mathrm{N}$ levels, and $40 \mathrm{Kg} \mathrm{N}^{-1}$ rate provided the maximum values in comparison with 0,20 and $60 \mathrm{Kg} \mathrm{N}$ fed $^{-1}$ rates. The authors found that the highest number of filled grains panicle $^{-1}$, Number of panicles $\mathrm{m}^{-2}$ and 1000 grain weight were obtained with $40 \mathrm{Kg} \mathrm{N}^{-1} \mathrm{ded}^{-1}$ rate. Jain et al. (2018) reported that application of $125 \mathrm{~kg} \mathrm{~N} / \mathrm{ha}$ gave significantly higher plant height, tillers $\mathrm{m}^{-2}$, panicles $\mathrm{m}^{-2}$, grains panicle ${ }^{-1}$, 1000 grain weight, grain and straw yields. In addition, nitrogen, phosphorus and potassium uptake significantly increased,also. However, $125 \mathrm{~kg} \mathrm{~N} / \mathrm{ha}$ dose was statistically at par with $100 \mathrm{~kg} \mathrm{~N} \mathrm{ha}^{-1}$ one.
"Small-flower"umbrella(Cyperus difformis L.) is considered as a serious competitor weed of rice crop in Egypt. Such weed is described as a vigorously growing weed with the capability to attain greater height, establish and develop extensive leaf area and horizontal branches when moisture and nutrients are not limiting, with respect to rice crop performance as affected by the associated weeds and its density. In connection, Estorninos et al. (2005) found that the number of tillers decreased from 20 to $48 \%$ with the increase of weeds density from 25 to 51 plants per $\mathrm{m}^{-2}$. Singh et al. (2005) reported $51.9 \%$ reduction in grain yield due to weed infestation was registered in weedy check treatment. Singh et al. (2007) stated that both weed density and dry weight were negatively correlated with rice grain yield. Aerobic directseeded rice treatment produced yield and net economic returns similar to conventionally puddled transplanted rice treatment when weeds were controlled. Kumar et al. (2008) reported that in the absence of weed control, rice yield get reduced by $35-100 \%$ in direct-seeded rice. Maity and Mukherjee (2008) reported that uncontrolled weeds reduced the grain yield by $96 \%$ in dry direct seeded rice and $61 \%$ in wet direct seeded rice. Singh et al. (2009) found that weed infestation in direct seeded rice resulted in yield loss up to 30 to $90 \%$, reduced grain quality and enhanced the cost of production. Sheeja et al. (2013) observed reductions in grain yield due to crop weed competition, compared to weed free situation, and $72 \%$ reduction in grain yield was noticed due to the infestation of broad leaved weeds and sedges in direct seeded rice.

The objective of the present work was to investigate the effect of Cyperus difformis $\mathrm{L}$. densities on rice crop performance under different nitrogen fertilization rates in Gharbia Governorate, Middle Nile Delta, Egypt.

\section{MATERIALS AND METHODS}

Two field experiments were conducted in heavily and natural infested soil with "smallflower"umbrella (Cyperus difformis L.) weed at Gemmeiza Agricultural Research Station Farm, Gharbia Governorate, Egypt, Agriculture Research Center, in the two summer seasons of 2015 and 2016. The experiments aimed at studying the effect of "small-flower" umbrella plant densities on rice growth and yield productivity under different nitrogen fertilization rates. Data of particle size distribution and some 
chemical soil analyses, according to Jackson (1973), are shown in Table (1). by manual thinning, and the remainder weed plants were covered with a plastic pots $15 \mathrm{~cm}$ in

Table (1): Particale size distribution and some chemical properties of the experimental soil in 2015 and 2016 seasons.

\begin{tabular}{|c|c|c|c|c|c|c|c|c|c|c|c|c|c|c|c|c|c|c|}
\hline \multirow{3}{*}{ 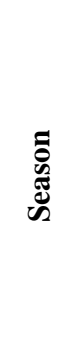 } & \multicolumn{3}{|c|}{$\begin{array}{l}\text { Particale size } \\
\text { distribution }\end{array}$} & \multirow{3}{*}{ 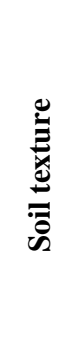 } & \multicolumn{14}{|c|}{ Chemical analyses } \\
\hline & \multirow[b]{2}{*}{ 总 } & \multirow[b]{2}{*}{$\begin{array}{l}\Delta^{0} \\
\stackrel{5}{5}\end{array}$} & \multirow[b]{2}{*}{$\frac{\vec{\theta}}{0}$} & & \multirow{2}{*}{ 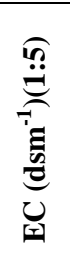 } & \multirow[b]{2}{*}{$\begin{array}{l}\stackrel{\widehat{7}}{\Xi} \\
\vec{z}\end{array}$} & \multirow{2}{*}{ 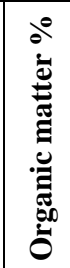 } & \multicolumn{4}{|c|}{ Available (mg kg-1) } & \multicolumn{7}{|c|}{$\begin{array}{c}\text { Soluble anions and cations } \\
\{\text { meq100g soil } \\
\end{array}$} \\
\hline & & & & & & & & 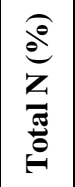 & $\underbrace{\stackrel{\Xi}{2}}_{\hat{a}}$ & 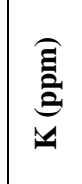 & 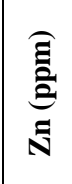 & $\overbrace{}^{\infty}$ & 官 & ப & $\stackrel{+}{+}$ & $\sum^{+\infty}$ & $\stackrel{+}{\mathbf{Z}}$ & $\stackrel{+}{ \pm}$ \\
\hline 2015 & 11.2 & 36.0 & 52.8 & Clay & 1.19 & 8.05 & 1.12 & 0.51 & 8.03 & 510.0 & 1.42 & 4.30 & 5.41 & 9.1 & 3.5 & 4.2 & 3.6 & 0.41 \\
\hline 2016 & 21.5 & 31.2 & 47.3 & Clay & 1.74 & 7.80 & 1.62 & 0.40 & 7.35 & 375.0 & 0.78 & 9.50 & 7.37 & 9.5 & 4.5 & 3.5 & 8.95 & 0.42 \\
\hline
\end{tabular}

Sakha 101 rice variety (Oryza sativa $\mathrm{L}$.) was assessed, and the preceding winter crop was wheat (Triticum astivum, L.) in both seasons. Seeded rice was broadcasted at 10 and 15 May in the first and second seasons, respectively, at $60 \mathrm{~kg} \mathrm{fed}^{-1}$ rate. The rice seeds were soaked in water for about 36 hours and then incubated for 24 hours. The other agricultural practices for rice production in the region were flowered. The adopted experimental treatments were laid out in split -plot design with four replicates. Plot area was $6.0 \mathrm{~m}^{2}(2.0 \mathrm{~m} \times 3.0 \mathrm{~m})$. Each experiment included eighteen treatments, which were the combination of three rates NPK of fertilizers added in the main plots and six small-flower umbrella densities allocated in sub plots as follows:

2.1. The main plots were occupied by the assessed $\mathrm{N}$ - fertilizer rates namely:

1. Nitrogen fertilizer $50 \mathrm{~kg} \mathrm{~N}_{\text {fed }}{ }^{-1}$

2. Nitrogen fertilizer $70 \mathrm{~kg} \mathrm{~N}_{\text {fed }}{ }^{-1}$

3. Nitrogen fertilizer $90 \mathrm{~kg} \mathrm{~N} \mathrm{fed}^{-1}$

Nitrogen fertilizers were added in the form of urea $(46.5 \% \mathrm{~N})$ in three equal doses as recommended for rice production in the area.

2.2.The sub-plots were assigned to the tested "small-flower"umbrella plant densities, namely

1- Zero small-flower umbrella plants $\mathrm{m}^{-2}$ (smallflower umbrella free)

2- 10 small-flower umbrella plants $\mathrm{m}^{-2}$

3- 20 small-flower umbrella plants $\mathrm{m}^{-2}$

4- 40 small-flower umbrella plants $\mathrm{m}^{-2}$

5- 80 small-flower umbrella plants $\mathrm{m}^{-2}$

6- 100 small-flower umbrella plants $\mathrm{m}^{-2}$ (as maximum natural infestation level in the experimental field).

After weeds emergence, the tested smallflowered umbrella plant densities were attained diameter. In order to control the other present weeds, Basagran $48 \%$ AS (bentazone) at rate $1.5 \mathrm{l} / \mathrm{fed}^{-1}$ was applied $21 \mathrm{DAS}$, and Web Super $75 \%$ EW (fenoxaprop-p-ethyl) at rate 300 $\mathrm{cm}^{3} \mathrm{fed}^{-1}$ was applied 10 days later. At 40 DAS the tested (Cyperus difformisL.) densities were re-thinned manually to the final required population per the square meter.

\subsection{Data recorded:}

2.3.1.Fresh and dry weight of rice plants $(\mathrm{g})$ :

A sample of rice plants were taken randomly from ten rice plants from each subplot at 70 and $90 \mathrm{DAS}$ and dried at $70^{\circ} \mathrm{C}$ (till the constant weight), and dry weight was determined as $\mathrm{g} \mathrm{m}^{-2}$.

\subsubsection{Rice grain yield and yield components:}

At harvest, ten guarded rice plants were hand pulled randomly from each sub-plot to determine plant height $(\mathrm{cm})$, panicle length $(\mathrm{cm})$, number of panicle $\mathrm{m}^{-2}$, number of full grain panicle $^{-1}, 1000$ - grain weight $(\mathrm{g})$, and all plants of the whole plot were harvested to determine grain and straw yields, which expressed as ton $\mathrm{fed}^{-1}$.

\subsection{Chemical analysis:}

At 60 and 80 DAS, five plants of both small-flower umbrella (Cyperus difformis L.) and rice plants were chosen randomly from each sub-plot and oven dried at $70^{\circ} \mathrm{C}$ to determine nitrogen, phosphorus and potassium $\%$ in dry matter of rice and small-flower umbrella plants.

At harvest, grain samples were also dried at $70^{\circ} \mathrm{C}$, and finally milled and wet digested according A.O.A.C. (1990) in order to determine nutrient concentrations. Total nitrogen was determined as described by Black (1965). Crude protein in rice grains was estimated by multiplying the total nitrogen \% in rice meal by 5.7 according to Tkachuk (1966). Phosphorus \% 
was determined calorimetrically, and potassium $\%$ was determined by flame photometer as described by Jackson (1973). N, P and K taken up by the grain yield were calculated by multiplying $\mathrm{N}, \mathrm{P}$ and $\mathrm{K} \%$ by rice grain (yield $\mathrm{fed}^{-1}$ ) and expressed as kg fed ${ }^{-1}$.

\subsection{Statistical analysis}

Statistical analysis was carried out according to Gomez and Gomez (1984) using "MSTAT-C" computer software. The means values were compared at $5 \%$ level of significance by using L.S.D. test. For regression study data were plotted and regression analyses were conducted. Linear $\hat{Y}=a+b X$ quadratic $\hat{Y}=a+b X-c X^{2}$ and cubic $\hat{Y}=a+b X+c$ $X^{2}+d X^{3}$ models were estimated to describe the relationship between the measured dependent variable of small-flower umbrella density (No. $\mathrm{m}^{-2}$ ) and independent variables rice grain yield $\left(\right.$ ton $\left.\mathrm{fed}^{-1}\right)$. $\hat{\mathrm{Y}}$, variables and $\mathrm{X}$, small-flower umbrella densities, a, b, c and d parameters represent intercept and slope of regression of variables and a regression models. The suitable model which fitted for prediction between the above mentioned variables quadratic regression analysis according to Sendecor and Cochran (1989) which is the correlation coefficient $\left(\mathrm{R}^{2}\right)$ was greater than other studied models and standard error values (SE) were smaller than those of the models.

\section{RESULTS AND DISCUSSION \\ 3.1. Effect of nitrogen fertilizer \\ 3.1.1.Fresh and dry weight of rice plants}

Data in Table (2) revealed that fresh and dry weights of rice plants at 70 and 90 days after sowing (DAS), tended to significantly increase at 0.05 level in both season by increasing nitrogen fertilizer rates from 50 up to $90 \mathrm{~kg} \mathrm{fed}^{-1}$ in both seasons. The incident increases due to the highest rate $\left(90 \mathrm{k} \mathrm{fed}^{-1}\right.$.) as compared to the lowest nitrogen rate reached 69.1 and $35.1 \%$ for rice fresh and dry weight at 70 DAS and 34.2 and $27.8 \%$ for rice fresh and dry weight at 90 DAS during the first season, respectively. The same trend was obtained in the second season with slight differences. The present findings showed that the highest dose of nitrogen fertilizer increased the growth of rice in terms of fresh and dry weights of the plants.In connection connection, Singh et al. (2017) reported that both rice and associated weeds plants exhibited higher leaf area, and showed more efficient biomass grain with increasing $\mathrm{N}$ input, and weed plants were superior in this respect.

\subsubsection{Yield and yield components}

Data in Table (3) illustrate that increasing nitrogen fertilizer rates significantly enhanced rice grain yield/fed and its components.

Nitrogen fertilizer rates, i.e. 70 and $90 \mathrm{~kg} \mathrm{~N}$ $\mathrm{fed}^{-1}$ rates induced significant increases comparing with $50 \mathrm{~kg} \mathrm{~N}$ fed $^{-1}$ rate, which reached to 4.6 and $9.9 \%$ in plant height, 15.02 and $30.40 \%$ in panicle $\mathrm{m}^{-2}, 4.21$ and $6.83 \%$ in panicle length, 10.03 and $12.93 \%$ in number full grain panicle ${ }^{-1}, 6.73$ and $11.11 \%$ in 1000grain weight, and 21.58 and $30.25 \%$ in straw yield in the first season, respectively. The same trend was observed with grain yield which significantly increased by 11.45 and $18.92 \%$ with 70 and $90 \mathrm{~kg} \mathrm{~N}^{-1}$ red rates, respectively, comparable with $50 \mathrm{~kg} \mathrm{~N}^{-1} \mathrm{fed}^{-1}$ rate in the first season. The corresponding increases in the second season, were 5.46 and $12.29 \%$ in plant height, 4.03 and $6.11 \%$ in panicle length , 17.59 and $36.34 \%$ in panicle $\mathrm{m}^{-2}, 10.34$ and $13.10 \%$ in number of full grains panicle ${ }^{-1}, 6.72$ and $11.12 \%$ in 1000-grain weight and 20.61 and $29.29 \%$ in straw yield and 12.98 and $18.95 \%$ grain yield, respectively. These results are in line with those of Singh et al. (2015) with direct seeded aerobic rice reported that growth and yield attributes viz. number of shoots, 1000 grain weight, number of grain panicle ${ }^{-1}$, grain and straw yields were higher in the treatment receiving $150 \mathrm{~kg} \mathrm{~N} \mathrm{ha}^{-1}$, comparable with 90 and $120 \mathrm{~kg} \mathrm{ha}^{-1}$ ones. In addition, Zimdahl (2004) found that nitrogen fertilizer increases the crop yield and improves the crop compatibility with the weeds, however, the addition of nutrient elements influenced the weed growth more than the crop when weed density is high.

3.1.3. NPK concentration of rice and (Cyperus difformis L.) plants

4. Generally, N, P and $\mathrm{K}$ concentrations in both rice and Cyperus difformis L. plants declined by elapsed time towards harvesting, indicating the translocation of the metabolized materials from the shoot to the storage organs. At 60 and 80 DAS, N concentration in (Cyperus difformis L.) plants was higher than that of rice plants. Whereas, P content exhibited an opposite trend, and such result was true at 60 and 80 DAS. $\mathrm{K}$ content in rice plants at 60 DAS exhibited higher values than in (Cyperus difformis L.) plants, and the trend was inversed at 80 DAS. 
Table (2): Effect of N-Fertilizer rates on fresh and dry weight (g) of rice plants at 70 and 90 DAS in 2015 and 2016 seasons.

\begin{tabular}{|c|c|c|c|c|c|c|c|c|}
\hline \multirow{2}{*}{$\begin{array}{c}\text { N -fertilizer } \\
\text { rates } \\
\text { kg fed }^{-1} \text { ) }\end{array}$} & \multicolumn{4}{|c|}{ 2015 season } & \multicolumn{4}{c|}{ 2016 season } \\
\cline { 2 - 8 } & \multicolumn{3}{|c|}{ Days after sowing (DAS) } & \multicolumn{4}{c|}{ Days after sowing (DAS) } \\
\cline { 2 - 9 } & $\mathbf{7 0}$ & $\mathbf{9 0}$ & $\mathbf{7 0}$ & $\mathbf{9 0}$ & $\mathbf{7 0}$ & $\mathbf{9 0}$ & $\mathbf{7 0}$ & $\mathbf{9 0}$ \\
\cline { 2 - 9 } & Fresh weight (g) & \multicolumn{2}{|c|}{ Dry weight (g) } & Fresh weight (g) & \multicolumn{2}{c|}{ Dry weight (g) } \\
\hline $\mathbf{5 0}$ & 159.3 & 298.1 & 21.1 & 52.6 & 163.5 & 303.9 & 21.7 & 56.3 \\
\hline $\mathbf{7 0}$ & 247.6 & 370.8 & 25.8 & 61.6 & 255.4 & 376.1 & 26.6 & 60.4 \\
\hline $\mathbf{9 0}$ & 269.4 & 400.1 & 28.5 & 64.2 & 276.7 & 406.9 & 29.3 & 65.1 \\
\hline LSD $_{\mathbf{0 . 0 5}}$ & 16.2 & 29.6 & 0.7 & 2.3 & 15.5 & 29.0 & $0 . .8$ & 1.9 \\
\hline
\end{tabular}

Table (3): Effect of N- Fertilizer rates on rice yield and its components in 2015 and 2016 seasons.

\begin{tabular}{|c|c|c|c|c|c|c|c|}
\hline 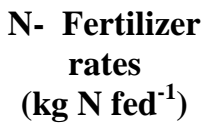 & $\begin{array}{l}\text { Plant } \\
\text { height } \\
(\mathrm{cm})\end{array}$ & $\begin{array}{c}\text { Panicle } \\
\text { length } \\
\text { (cm) }\end{array}$ & \begin{tabular}{|c|} 
No. \\
Panicles \\
$\mathbf{m}^{-2}$
\end{tabular} & $\begin{array}{c}\text { No. } \\
\text { full grain } \\
\text { panicle }^{-1}\end{array}$ & $\begin{array}{c}1000 \\
\text { grain } \\
\text { weight }(\mathrm{g})\end{array}$ & $\begin{array}{c}\text { Straw } \\
\text { yield } \\
\left(\text { ton fed }^{-1}\right)\end{array}$ & $\begin{array}{c}\text { Grain } \\
\text { yield } \\
\left.\text { (ton fed }^{-1}\right)\end{array}$ \\
\hline & \multicolumn{7}{|c|}{2015 season } \\
\hline 50 & 89.01 & 22.55 & 120.9 & 104.7 & 21.24 & 5.19 & 2.96 \\
\hline 70 & 93.10 & 23.50 & 139.0 & 115.2 & 22.67 & 6.31 & 3.30 \\
\hline 90 & 97.80 & 24.09 & 157.6 & 118.2 & 23.60 & 6.76 & 3.52 \\
\hline \multirow[t]{2}{*}{$\mathbf{L S D}_{0.05}$} & 2.73 & 0.16 & 6.8 & 1.14 & 0.92 & 0.38 & 0.06 \\
\hline & \multicolumn{7}{|c|}{2016 season } \\
\hline 50 & 81.34 & 22.08 & 114.2 & 106.3 & 21.14 & 4.95 & 2.85 \\
\hline 70 & 85.78 & 22.97 & 134.3 & 117.3 & 22.56 & 5.97 & 3.22 \\
\hline 90 & 91.34 & 23.43 & 155.7 & 120.2 & 23.49 & 6.40 & 3.39 \\
\hline LSD $_{0.05}$ & 2.65 & 0.23 & 7.17 & 0.49 & 1.01 & 0.38 & 0.10 \\
\hline
\end{tabular}

Results in Table (4) revealed that nitrogen fertilizer rates had a significantly effect on N, P and $\mathrm{K} \%$ of rice and Cyperus difformis L. plants at 60 , and $80 \mathrm{DAS}$, except $\mathrm{P} \%$ in rice plants at 8060 DAS in the first season. In the second season both $\mathrm{N}$ and $\mathrm{P}$ contents in rice at 80 and 60 DAS, respectively, and $\mathrm{P}$ in Cyperus difformis L. at 60 DAS was not significantly affected due to the tested N-rates. Increasing nitrogen fertilizer from 50 to 80 or $90 \mathrm{~kg} \mathrm{~N} \mathrm{fed}^{-1}$ rates seemed to increase $\mathrm{N}, \mathrm{P}$ and $\mathrm{K} \%$ of rice and Cyperus difformis L. plants at 60 and 80 DAS in both seasons, respectively.

\subsubsection{N, $P$ and $K$ concentrations and nutrients} uptake in rice grains:

Significant increases in N, P and K uptake in rice grain were noticed by increasing nitrogen fertilizer rate to 70 or $90 \mathrm{~kg} \mathrm{~N} \mathrm{fed}^{-1}$, Table (5) which resulted in increases amounted to (22.22 and $35.55 \%),(18.76$ and $54.64 \%)$ and (59.51 and $72.82 \%)$ in the first season and to (23.86 and $32.22 \%),(24.74$ and $48.41 \%)$ and (23.07and $46.43 \%$ ) in the second season, respectively, compared to $50 \mathrm{~kg} \mathrm{~N}$ fed $^{-1}$. Furthermore, grain protein $\%$ was not significantly affected by nitrogen fertilizer treatments in the first season, however, higher figures were noticed with higher N rates. Significant effect was exerted to alter protein \% in the second season, and higher values still exhibited with higher $\mathrm{N}$ rate.

\subsection{Effect of small-flower umbrella (Cyperus} difformis $\mathbf{L}$.) densities.

\subsubsection{Fresh and dry weight of rice plants:}

Data in Table (6) indicate that the adopted densities of Cyperus difformis, $L$. had significant effects on fresh and dry weight of rice plants at 70 or 90 DAS in both seasons. The densities of $10,20,40,80$ and 100 plants $\mathrm{m}^{-2}$ reduced fresh weight of rice plants by 9.07, 18.58, 32.21, 44.76 and $73.17 \%$ and reduced dry weight of rice plants by $7.8,16.4,51.84,73.28$ and 85.94 $\%$ at 70 DAS, respectively, compared to Zero density in the first season. At 90 DAS reduction in rice fresh weight were 11.59, 20.47, 25.86, 44.84 and $71.81 \%$. Whereas the reduction values in rice dry matter were $12.87,23.94,50.72$, 67.98 and $78.29 \%$, respectively, in the first 
Table (4): Effect of $\mathrm{N}$-fertilizer rates on nutrients concentration of rice and small-flower umbrella, Cyperus difformis, L. plants at 60 and 80 DAS in 2015 and 2016 seasons.

\begin{tabular}{|c|c|c|c|c|c|c|c|c|c|c|c|c|}
\hline \multirow{4}{*}{$\begin{array}{c}\text { N-fertilizer } \\
\text { rates } \\
\left(\mathrm{Kg} \mathrm{N} \mathrm{fed}^{-1}\right)\end{array}$} & \multicolumn{4}{|c|}{ Nitrogen $\%$} & \multicolumn{4}{|c|}{ Phosphorus \% } & \multicolumn{4}{|c|}{ Potassium \% } \\
\hline & \multicolumn{2}{|c|}{ Rice } & \multicolumn{2}{|c|}{ C. difformis } & \multicolumn{2}{|c|}{ Rice } & \multicolumn{2}{|c|}{ C. difformis } & \multicolumn{2}{|c|}{ Rice } & \multicolumn{2}{|c|}{ C. difformis } \\
\hline & \multicolumn{12}{|c|}{ Days after sowing, DAS } \\
\hline & 60 & 80 & 60 & 80 & 60 & 80 & 60 & 80 & 60 & 80 & 60 & 80 \\
\hline \multicolumn{13}{|c|}{2015 season } \\
\hline 50 & 2.25 & 1.27 & 2.96 & 1.53 & 0.162 & 0.090 & 0.142 & 0.089 & 2.93 & 1.65 & 2.75 & 1.78 \\
\hline 70 & 3.26 & 1.36 & 3.36 & 1.67 & 0.173 & 0.101 & 0.150 & 0.105 & 3.18 & 1.79 & 2.87 & 1.88 \\
\hline 90 & 3.48 & 1.45 & 3.93 & 1.88 & 0.182 & 0.129 & 0.157 & 0.110 & 3.34 & 1.87 & 3.08 & 1.93 \\
\hline LSD $_{0.05}$ & 0.30 & 0.15 & 0.21 & 0.20 & NS & 0.04 & 0.03 & 0.03 & 0.18 & 0.06 & 0.28 & 0.08 \\
\hline \multicolumn{13}{|c|}{2016 season } \\
\hline 50 & 2.34 & 1.19 & 2.83 & 1.43 & 0.153 & 0.085 & 0.134 & 0.080 & 2.87 & 1.62 & 2.54 & 1.68 \\
\hline 70 & 3.17 & 1.24 & 3.25 & 1.53 & 0.164 & 0.091 & 0.136 & 0.084 & 3.11 & 1.66 & 2.80 & 1.77 \\
\hline 90 & 3.31 & 1.31 & 3.88 & 1.68 & 0.169 & 0.126 & 0.141 & 0.095 & 3.29 & 1.69 & 3.11 & 1.85 \\
\hline LSD $_{0.05}$ & 0.10 & NS & 0.13 & 0.08 & NS & 0.01 & NS & 0.01 & 0.13 & 0.05 & 0.24 & 0.04 \\
\hline
\end{tabular}

$\mathrm{NS}=$ nonsignificant at 0.05 level

Table (5): Effect of $\mathrm{N}$ - fertilizer rates on nutrient concentration and uptake by grain rice in 2015 and 2016 seasons.

\begin{tabular}{|c|c|c|c|c|c|c|c|}
\hline \multirow{3}{*}{$\begin{array}{l}\text { N fertilizer rates } \\
\qquad\left(\mathrm{Kg} \mathrm{fed}^{-1}\right)\end{array}$} & \multicolumn{3}{|c|}{ Nutrient \% } & \multicolumn{3}{|c|}{ Nutrient uptake $\left(\mathrm{kg} \mathrm{fed}^{-1}\right)$} & \multirow{2}{*}{$\begin{array}{c}\text { Protein } \\
\%\end{array}$} \\
\hline & $\mathbf{N}$ & $\mathbf{P}$ & $\mathbf{K}$ & $\mathbf{N}$ & $\mathbf{P}$ & $\mathbf{K}$ & \\
\hline & \multicolumn{7}{|c|}{2015 season } \\
\hline 50 & 1.87 & 0.306 & 0.302 & 55.35 & 9.06 & 8.94 & 10.66 \\
\hline 70 & 2.05 & 0.326 & 0.432 & 67.65 & 10.76 & 14.26 & 11.69 \\
\hline 90 & 2.11 & 0.398 & 0.439 & 73.92 & 14.01 & 15.45 & 12.03 \\
\hline \multirow[t]{2}{*}{ LSD $_{0.05}$} & NS & 0.01 & 0.01 & 2.36 & 0.30 & 0.13 & $\mathrm{NS}$ \\
\hline & \multicolumn{7}{|c|}{2016 season } \\
\hline 50 & 1.97 & 0.363 & 0.368 & 56.15 & 10.35 & 10.49 & 11.22 \\
\hline 70 & 2.16 & 0.401 & 0.401 & 69.55 & 12.91 & 12.91 & 12.29 \\
\hline 90 & 2.19 & 0.453 & 0.453 & 74.24 & 15.36 & 15.36 & 12.48 \\
\hline LSD $_{0.05}$ & 0.19 & 0.05 & 0.05 & 1.56 & 1.38 & 1.82 & 0.10 \\
\hline
\end{tabular}

$\mathrm{NS}=$ nonsignificant at 0.05 level

Table (6): Effect of small-flower umbrella ,Cyperus difformis, L. densities on fresh and dry weight $(\mathrm{g})$ of rice plants in 2015 and 2016 seasons.

\begin{tabular}{|c|c|c|c|c|c|c|c|c|}
\hline \multirow{4}{*}{$\begin{array}{c}\text { Cyperus } \\
\text { difformis L. } \\
\text { densities } \\
\left(\text { plant } \mathbf{m}^{-2}\right)\end{array}$} & \multicolumn{4}{|c|}{2015 season } & \multicolumn{4}{|c|}{2016 season } \\
\hline & \multicolumn{2}{|c|}{ Fresh weight (g) } & \multicolumn{2}{|c|}{ Dry weight (g) } & \multicolumn{2}{|c|}{ Fresh weight (g) } & \multicolumn{2}{|c|}{ Dry weight (g) } \\
\hline & \multicolumn{8}{|c|}{ Days After Sowing, DAS } \\
\hline & 70 & 90 & 70 & 90 & 70 & 90 & 70 & 90 \\
\hline Zero & 184.1 & 317.5 & 26.68 & 58.65 & 191.9 & 347.3 & 28.11 & 55.14 \\
\hline 10 & 167.4 & 280.7 & 22.40 & 51.10 & 176.8 & 290.2 & 21.37 & 46.84 \\
\hline 20 & 149.9 & 252.5 & 22.40 & 44.61 & 158.3 & 247.3 & 18.58 & 37.89 \\
\hline 40 & 124.8 & 235.4 & 12.85 & 28.90 & 137.5 & 226.8 & 14.53 & 31.68 \\
\hline 80 & 101.7 & 175.2 & 7.13 & 18.78 & 108.9 & 181.1 & 7.80 & 21.59 \\
\hline 100 & 49.4 & 89.5 & 3.75 & 12.73 & 55.4 & 95.5 & 4.03 & 16.29 \\
\hline LSD $_{0.05}$ & 25.60 & 47.30 & 1.68 & 3.99 & 25.47 & 46.83 & 1.81 & 4.09 \\
\hline
\end{tabular}


season compared to Zero density, in the same order of the abovementioned weed densities. The same trend was obtained in the second season with slight differences. The reduction in fresh and dry weight of rice plants with increasing Cyperus difformis L. plant density may be attributed to competition due to high ability of this weed to absorb nutrients and increased vegetative growth.

\subsubsection{Rice yield and yield components:}

Data in Table (7) show that plant height $(\mathrm{cm})$, panicle length $(\mathrm{cm})$, No. panicles $\mathrm{m}^{-2}$, No. full grain / panicles, 1000 grain weight (g), grain yield (ton $\mathrm{fed}^{-1}$ ) and straw yields (ton fed ${ }^{-1}$ ) were significantly affected by Cyperus difformis L. densities $\mathrm{m}^{-2}$ in both seasons. These parameters were progressively reduced by increasing Cyperus difformis L. density during the two growing seasons. The highest Cyperus difformis, L. density (100 plants $\mathrm{m}^{-2}$ ) induced the highest reduction in plant height, panicle length, No. panicle $\mathrm{m}^{-2}$, No. full grain panicle ${ }^{-1}, 1000$ - grain weight and straw yield, which comprised (25.7 and $28.7 \%$ ), (19.8 and $19.7 \%)$, ( 69.9 and 73.9 $\%),(59.94$ and $63.22 \%),(16.6$ and $16.7 \%)$ and (44.2 and $48.2 \%$ ), respectively, in the first and second seasons, compared with weed free treatment.

Furthermore, increasing Cyperus difformis L. density led to decreasing rice grain yield, where densities of $10,20,40,80$, and 100 Cyperus difformis L. plants $\mathrm{m}^{-2}$ reduced the grain yield by $5.37,14.42,22.24,32.03$ and $47.43 \%$ as compared to zero density, respectively. Similar trend was obtained in the second season, since the abovementioned Cyperus difformis L. densities resulted in decreased rice grain yield values amounted to $7.98,14.96,22.94,32.92$ and $48.88 \%$, respectively, comparable with zero density. Such reductions may be due to the decrease in yield components e.g. plant height, panicle length, No. panicle $\mathrm{m}^{-2}$, No. full grain panicle ${ }^{-1}$, and 1000 grains weight. These results are in harmony with those obtained by Singh et al. (2007), Mamun et al. (2013) and Sheeja et al. (2013).

\subsubsection{NPK concentration of rice and Cyperus difformis L. plants.}

Data in Table (8) showed that the adopted Cyperus difformis L. densities significantly affected N, P and K \% of rice and Cyperus difformis L. plants at 60 and 80 DAS in both seasons, except $\mathrm{P} \%$ in both rice and Cyperus difformis L. plants at 60 DAS in the first season. The highest values of $\mathrm{N}, \mathrm{P}$ and $\mathrm{K} \%$ in rice plants at 60 and 80 DAS were observed from weed free treatment, whereas the lowest values were obtained from density of 100 Cyperus difformis L. plants $\mathrm{m}^{-2}$ in both seasons. While, the maximum $\mathrm{N}, \mathrm{P}$ and $\mathrm{K} \%$ in Cyperus difformis L. at 60 and 80 DAS were obtained from density of 10 Cyperus difformis $\mathrm{L}$. plants $\mathrm{m}^{-2}$ and the lowest values were observed from density of 100 Cyperus difformis L. plants $\mathrm{m}^{-2}$ in both seasons. Similar results were obtained by Seema and Tohi (2010).

Table (7): Effect of small-flower umbrella ,Cyperus difformis, L. densities on rice yield and its components in 2015 and 2016 seasons.

\begin{tabular}{|c|c|c|c|c|c|c|c|}
\hline \multirow[t]{2}{*}{$\begin{array}{l}\text { Cyperus difformis } \\
\text { L. densities } \\
\text { (plant } \mathbf{m}^{-2} \text { ) }\end{array}$} & $\begin{array}{l}\text { Plant height } \\
\text { (cm) }\end{array}$ & $\begin{array}{l}\text { Panicle } \\
\text { length } \\
\text { (cm) }\end{array}$ & $\begin{array}{c}\text { No. } \\
\text { panicles } \\
\text { m}^{-2}\end{array}$ & $\begin{array}{c}\text { No. full } \\
\text { grain } \\
\text { panicle }^{-1}\end{array}$ & $\begin{array}{c}\text { 1000-grain } \\
\text { weight } \\
\text { (g) }\end{array}$ & $\begin{array}{c}\text { Straw } \\
\text { yield } \\
\left.\text { (ton fed }^{-1}\right)\end{array}$ & $\begin{array}{c}\text { Grain Yield } \\
\left(\text { ton fed }^{-1}\right)\end{array}$ \\
\hline & \multicolumn{7}{|c|}{2015 season } \\
\hline Zero & 105.03 & 25.12 & 205.08 & 131.67 & 24.69 & 7.40 & 4.09 \\
\hline 10 & 101.36 & 24.70 & 186.67 & 126.08 & 23.60 & 7.09 & 3.87 \\
\hline 20 & 97.12 & 24.28 & 167.25 & 116.08 & 22.73 & 6.61 & 3.50 \\
\hline 40 & 91.69 & 23.53 & 126.08 & 107.42 & 22.19 & 5.95 & 3.18 \\
\hline 80 & 86.54 & 22.52 & 88.33 & 72.9 & 21.20 & 5.32 & 2.78 \\
\hline 100 & 78.08 & 20.15 & 61.67 & 52.75 & 20.60 & 4.13 & 2.15 \\
\hline \multirow[t]{2}{*}{ LSD $_{0.05}$} & 1.84 & 0.15 & 9.19 & 1.89 & 0.58 & 0.23 & 0.05 \\
\hline & \multicolumn{7}{|c|}{2016 season } \\
\hline Zero & 98.40 & 24.51 & 202.50 & 133.67 & 24.60 & 7.08 & 4.01 \\
\hline 10 & 94.54 & 24.15 & 184.58 & 127.67 & 23.49 & 6.86 & 3.69 \\
\hline 20 & 90.24 & 23.69 & 165.25 & 117.67 & 22.63 & 6.29 & 3.41 \\
\hline 40 & 84.58 & 22.95 & 116.17 & 109.33 & 22.09 & 5.71 & 3.09 \\
\hline 80 & 79.68 & 22.00 & 86.75 & 69.00 & 21.08 & 5.00 & 2.69 \\
\hline 100 & 70.13 & 19.67 & 52.92 & 49.17 & 20.50 & 3.67 & 2.05 \\
\hline LSD $_{0.05}$ & 3.34 & 0.59 & 9.57 & 3.33 & 0.60 & 0.37 & 0.12 \\
\hline
\end{tabular}


Table (8): Effect of (Cyperus difformis $\mathbf{L}$.) density $\mathrm{m}^{-2}$ on nutrient concentration in rice and smallflower umbrella, (Cyperus difformis L.) plants at 60 and 80 DAS in 2015 and 2016 seasons

\begin{tabular}{|c|c|c|c|c|c|c|c|c|c|c|c|c|}
\hline \multirow{5}{*}{$\begin{array}{c}\text { Cyperus } \\
\text { difformis } \mathbf{L} \text {. } \\
\text { Densities } \mathbf{m}^{-2}\end{array}$} & \multicolumn{4}{|c|}{ Nitrogen \% } & \multicolumn{4}{|c|}{ Phosphorus \% } & \multicolumn{4}{|c|}{ Potassium \% } \\
\hline & \multicolumn{2}{|c|}{ Rice } & \multicolumn{2}{|c|}{ C. difformis } & \multicolumn{2}{|c|}{ Rice } & \multicolumn{2}{|c|}{ C. difformis } & \multicolumn{2}{|c|}{ Rice } & \multicolumn{2}{|c|}{ C. difformis } \\
\hline & \multicolumn{12}{|c|}{ Days after sowing, DAS } \\
\hline & 60 & 80 & 60 & 80 & 60 & 80 & 60 & 80 & 60 & 80 & 60 & 80 \\
\hline & \multicolumn{12}{|c|}{2015 season } \\
\hline zero & 3.61 & 1.75 & - & - & 0.20 & 0.15 & & - & 3.73 & 2.21 & - & 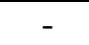 \\
\hline 10 & 3.42 & 1.46 & 3.87 & 2.13 & 0.19 & 0.13 & 0.16 & 0.13 & 3.52 & 1.92 & 3.49 & 2.09 \\
\hline 20 & 3.19 & 1.38 & 3.56 & 1.94 & 0.17 & 0.11 & 0.15 & 0.11 & 3.33 & 1.75 & 3.13 & 1.98 \\
\hline 40 & 2.88 & 1.29 & 3.39 & 1.66 & 0.16 & 0 & 0 & 0 & 3.21 & 1.64 & 3.06 & 79 \\
\hline 80 & 2.63 & 1.07 & 3.11 & 1.50 & 0.15 & 0 & & 0 & 2. & 1.56 & 2.81 & 51 \\
\hline 100 & 2.44 & 1.00 & 2.77 & 1.21 & 0.14 & 0.08 & 0.13 & 0.07 & 2.83 & 1.41 & 2.45 & 1.47 \\
\hline \multirow[t]{2}{*}{ LSD $_{0.05}$} & 0.11 & 0.15 & 0.18 & 0.11 & NS & 0.01 & NS & 0.01 & 0.12 & 0.07 & \begin{tabular}{|l|}
0.21 \\
\end{tabular} & 0.12 \\
\hline & \multicolumn{12}{|c|}{2016 season } \\
\hline zero & 3.50 & 1.69 & - & - & 0.19 & 0.14 & - & - & 3.57 & \begin{tabular}{|l|}
2.04 \\
\end{tabular} & - & - \\
\hline 10 & 3.33 & 1.36 & 3.86 & 2.06 & 0.18 & 0.12 & 0.16 & 0.12 & 3.36 & 1.84 & \begin{tabular}{|l|}
3.59 \\
\end{tabular} & 2.14 \\
\hline 20 & 3.11 & 1.25 & 3.64 & 1.81 & 0.17 & 0.10 & 0.14 & 0.09 & 3.25 & 1.66 & 3.03 & 1.93 \\
\hline 40 & 2.76 & 1.17 & 3.42 & 1.44 & 0.16 & 0.09 & 0.14 & 0.08 & 3.04 & 1.56 & 2.80 & 1.73 \\
\hline 80 & 2.56 & 1.00 & 3.03 & 1.31 & 0.14 & 0.08 & 0.13 & 0.07 & 3.84 & 1.51 & 2.51 & 1.58 \\
\hline 100 & 2.36 & 1.00 & 2.67 & 1.14 & 0.14 & 0.07 & 0.12 & 0.07 & 2.84 & 1.35 & 2.15 & 1.42 \\
\hline LSD $_{0.0}$ & 0.10 & 0.13 & 0.15 & 0.09 & 0.01 & 0.01 & \begin{tabular}{|l|}
0.01 \\
\end{tabular} & 0.01 & 0.12 & 0.06 & \begin{tabular}{|l|}
0.19 \\
\end{tabular} & $\mathbf{0 . 0 7}$ \\
\hline
\end{tabular}

$\mathrm{NS}=$ non-significant

\subsubsection{NPK concentration and uptake in rice grains}

As shown in Table (9) N, P and $\mathrm{K}$ percentages or uptake as well as grain protein percentage were reduced by increasing Cyperus difformis L. denisty. The highest density 100 Cyperus difformis L. plants $\mathrm{m}^{-2}$ recorded the highest reduction values of nutrient $\%$, where the reduction were $17.37,33.49$ and $18.90 \%$ for $\mathrm{N}$, $\mathrm{P}$ and $\mathrm{K} \%$, respectively, compared with weed free treatment in the first season and by 8.84 , 21.22 and $27.26 \%$, respectively, in the second season. $\mathrm{N}, \mathrm{P}$ and $\mathrm{K}$ uptake values exhibited similar trend, and comprised 56.57, 65.06 and $57.41 \%$, respectively, in the first season and, $53.40,59.74$ and $62.81 \%$, respectively, in the second season. Likely, protein content of rice grain took the same trend, since the highest Cyperus difformis, L. density (100 plants $\mathrm{m}^{-2}$ ) reduced it by 17.38 and $8.89 \%$ in the first and second seasons, respectively compared with zero Cyperus difformis, L. plants $\mathrm{m}-2$. These results suggest that Cyperus difformis, L. strongly competed with rice crop for $\mathrm{N}, \mathrm{P}$ and $\mathrm{K}$ nutrients in particular with nitrogen. Similar results were obtained by Singh et al. (2009).

\subsection{Effect of interaction between nitrogen fertilizer and (Cyperus difformi L.) densities}

\subsubsection{Fresh and dry weight of rice plants:}

Data in Table (10) revealed that all interaction between nitrogen fertilizer and Cyperus difformis L. densities had statistically significant effect on rice fresh and dry weight at 70 and 90 DAS. The maximum fresh and dry weight of rice plant at 70 and 90 DAS were 186.8 and $432.6 \mathrm{~g}$ and 34.4 and $59.6 \mathrm{~g}$, respectively, were recorded from weed free treatment as interacted with $90 \mathrm{~kg} \mathrm{~N}^{-1} \mathrm{ded}^{-1}$ rate, whereas, the minimum values of fresh and dry weight at 70 DAS (178.8 and $27.7 \mathrm{~g}$ ) and at 90 DAS (293.9 and 56.4g) were observed from interaction of 100 Cyperus difformis, L. plants $\mathrm{m}^{-2}$ treatment and $50 \mathrm{~kg} N$ fed $^{-1}$ rate, respectively in the first season. The same trend was obtained in the second season with slight differences.

\subsubsection{Yield and yield components:}

Data in Table (11) show that all interaction between nitrogen fertilizer and Cyperus difformis L. densities had statistically significant effect on all of the studied parameters of grain 
Table (9): Effect of small-flower umbrella, Cyperus difformis densities $\mathbf{m}^{-2}$ on nutrient concentration and Uptake by grain rice in 2015 and 2016 seasons .

\begin{tabular}{|c|c|c|c|c|c|c|c|}
\hline \multirow{3}{*}{$\begin{array}{l}\text { Cyperus difformis } \\
\text { densities } \mathbf{m}^{-2}\end{array}$} & \multicolumn{3}{|c|}{ Nutrient content $\%$} & \multicolumn{3}{|c|}{$\begin{array}{l}\text { Nutrient uptake } \\
\left(\mathrm{kg} \mathrm{fed}^{-1}\right)\end{array}$} & \multirow{2}{*}{$\begin{array}{c}\text { Protein } \\
\%\end{array}$} \\
\hline & $\mathbf{N}$ & $\mathbf{P}$ & $\mathbf{K}$ & $\mathbf{N}$ & $\mathbf{P}$ & $\mathbf{K}$ & \\
\hline & \multicolumn{7}{|c|}{2015 season } \\
\hline zero & 2.13 & 0.415 & 0.439 & 87.12 & 16.97 & 17.96 & 12.14 \\
\hline 10 & 2.11 & 0.382 & 0.411 & 81.66 & 14.78 & 15.91 & 11.97 \\
\hline 20 & 2.07 & 0.359 & 0.390 & 72.45 & 12.57 & 13.65 & 11.80 \\
\hline 40 & 2.03 & 0.320 & 0.379 & 64.55 & 10.18 & 12.05 & 11.57 \\
\hline 80 & 1.94 & 0.309 & 0.369 & 53.93 & 8.59 & 10.26 & 11.06 \\
\hline 100 & 1.76 & 0.276 & 0.356 & 37.84 & 5.93 & 7.65 & 10.03 \\
\hline \multirow[t]{2}{*}{ LSD $_{0.05}$} & 0.23 & 0.02 & 0.01 & 2.87 & 0.51 & 0.37 & 1.31 \\
\hline & \multicolumn{7}{|c|}{2016 season } \\
\hline zero & 2.15 & 0.443 & 0.521 & 86.22 & 17.76 & 20.89 & 12.26 \\
\hline 10 & 2.10 & 0.468 & 0.454 & 77.49 & 17.27 & 16.75 & 12.09 \\
\hline 20 & 2.09 & 0.409 & 0.476 & 71.27 & 13.95 & 16.23 & 11.91 \\
\hline 40 & 2.04 & 0.395 & 0.428 & 63.04 & 12.21 & 13.23 & 11.63 \\
\hline 80 & 2.00 & 0.369 & 0.415 & 53.80 & 9.93 & 11.16 & 11.40 \\
\hline 100 & 1.96 & 0.349 & 0.379 & 40.18 & 7.15 & 7.77 & 11.17 \\
\hline LSD $_{0.05}$ & 0.23 & 0.05 & 0.08 & 1.09 & 1.40 & 2.24 & 0.11 \\
\hline
\end{tabular}

Table (10): Effect of interaction between $\mathrm{N}$-fertilizer rates and small-flower umbrella, (Cyperus difformis L.) densities on fresh and dry weight (g) of rice plants in 2015 and 2016 seasons.

\begin{tabular}{|c|c|c|c|c|c|c|c|c|c|}
\hline \multirow{4}{*}{$\begin{array}{c}\mathrm{N} \\
\text { Fertilizer } \\
\text { rates }(\mathbf{k g} \\
\left.\mathrm{N} \mathrm{fed}^{-1}\right)\end{array}$} & \multirow{4}{*}{$\begin{array}{c}\text { (Cyperus } \\
\text { difformis) } \\
\text { densities }\end{array}$} & \multicolumn{4}{|c|}{2015 season } & \multicolumn{4}{|c|}{2016 season } \\
\hline & & \multicolumn{2}{|c|}{ Fresh weight (g) } & \multicolumn{2}{|c|}{ Dry weight (g ) } & \multicolumn{2}{|c|}{ Fresh weight (g ) } & \multicolumn{2}{|c|}{ Dry weight (g) } \\
\hline & & & & & $s$ after & wing, D & & & \\
\hline & & 70 & 90 & 70 & 90 & 70 & 90 & 70 & 90 \\
\hline \multirow{6}{*}{50} & Zero & $\begin{array}{l}178.8 \\
\end{array}$ & 293.9 & 27.7 & 56.4 & 183.8 & 304.3 & 29.3 & 58.6 \\
\hline & 10 & 173.5 & 252.5 & 23.8 & 46.6 & 170.7 & 262.9 & 24.2 & 48.7 \\
\hline & 20 & 149.0 & 235.0 & 20.0 & 37.7 & 153.8 & 241.9 & 21.1 & 39.8 \\
\hline & 40 & 127.6 & 154.4 & 14.0 & 32.6 & 132.6 & 160.0 & 16.5 & 32.7 \\
\hline & 80 & 67.4 & 96.8 & 10.1 & 21.6 & 73.4 & 102.4 & 11.4 & 22.7 \\
\hline & 100 & 32.8 & 68.8 & 7.7 & 16.1 & 37.8 & 75.1 & 9.8 & 17.2 \\
\hline \multirow{6}{*}{70} & Zero & 1838 & 379.8 & 32.9 & 59.9 & 197.5 & 389.0 & 34.2 & 59.1 \\
\hline & 10 & 176.9 & 280.1 & 27.6 & 49.0 & $\begin{array}{l}189.3 \\
\end{array}$ & 381.7 & 29.1 & 47.5 \\
\hline & 20 & 138.5 & 253.4 & 21.7 & 38.9 & 165.5 & 254.1 & 23.7 & 41.0 \\
\hline & 40 & 120.0 & 231.0 & 18.5 & 32.1 & 110.8 & 233.3 & 18.2 & 33.6 \\
\hline & 80 & 111.3 & 114.0 & 12.8 & 26.5 & 79.0 & 169.8 & 12.7 & 27.3 \\
\hline & 100 & 50.3 & 92.5 & 9.2 & 18.0 & 59.5 & 98.4 & 10.6 & 19.4 \\
\hline \multirow{6}{*}{90} & Zero & 186.8 & 432.6 & 34.4 & 59.6 & 199.3 & 348.8 & 35.8 & 59.9 \\
\hline & 10 & 164.5 & 383.5 & 29.8 & 47.3 & 168.3 & 393.0 & 29.9 & 48.6 \\
\hline & 20 & 146.3 & 389.0 & 25.5 & 40.2 & 145.5 & 279.3 & 26.9 & 42.4 \\
\hline & 40 & 121.8 & 167.1 & 20.1 & 35.0 & 123.3 & 153.0 & 21.9 & 35.1 \\
\hline & 80 & 112.5 & 132.8 & 13.5 & 26.3 & 114.3 & 121.3 & 14.4 & 28.2 \\
\hline & 100 & 65.3 & 101.1 & 9.4 & 19.1 & 69.0 & 113.0 & 10.8 & 19.8 \\
\hline
\end{tabular}

yield and its components, and such results were true in the first and second seasons. The highest value of plant height $(107.98$ and $102.18 \mathrm{~cm})$, panicle length $(25.57$ and $24.77 \mathrm{~cm})$,number panicles $\mathrm{m}^{-2}$ (218.50 and 216.25), number full grain panicle $^{-1}$ (138.25 and 140.00),1000-grain weight (25.57 and $25.47 \mathrm{~g}$ ),straw(7.88 and 7.56 ton $\left.\mathrm{fed}^{-1}\right)$ and grain yield(4.21and 4.15 ton $\left.\mathrm{fed}^{-1}\right)$, respectively, in the first and second seasons were obtained from adding $90 \mathrm{~kg} \mathrm{~N} / \mathrm{fed}$. In the absence of (Cyperus difformis L.) competition.

On the other hand, the lowest values of the abovementioned parameters, in the first and second seasons were $(69.73$ and $60.35 \mathrm{~cm})$, 
Table (11): Effect of interaction between $\mathrm{N}$ - fertilizer rates and small-flower umbrella,Cyperus difformis $L$. densities on rice grain yield and its components in 2015 and 2016 seasons.

\begin{tabular}{|c|c|c|c|c|c|c|c|c|}
\hline \multirow[t]{2}{*}{$\begin{array}{l}\text { N- nitrogen } \\
\text { rates }(\mathrm{kg} N \\
\left.\text { fed }^{-1}\right)\end{array}$} & \multirow[t]{2}{*}{$\begin{array}{c}\text { (Cyperus } \\
\text { difformis) } \\
\text { densities }\end{array}$} & $\begin{array}{l}\text { Plant } \\
\text { height } \\
(\mathrm{cm})\end{array}$ & $\begin{array}{l}\text { Panicle } \\
\text { length } \\
\text { (cm) }\end{array}$ & $\begin{array}{c}\text { No. } \\
\text { Panicles } \\
\text { m }^{-2}\end{array}$ & $\begin{array}{l}\text { No. full } \\
\text { grain } \\
\text { panicle }^{-1}\end{array}$ & $\begin{array}{c}\text { 1000- } \\
\text { grain } \\
\text { Weight } \\
\text { (g) }\end{array}$ & $\begin{array}{c}\text { Straw } \\
\text { yield } \\
\left(\text { ton fed }^{-1}\right)\end{array}$ & $\begin{array}{c}\text { Grain } \\
\text { yield } \\
\left(\text { ton }_{\text {fed }}{ }^{-1}\right)\end{array}$ \\
\hline & & \multicolumn{7}{|c|}{2015 season } \\
\hline \multirow{6}{*}{50} & Zero & 101.80 & 24.70 & 190.00 & 122.50 & 23.65 & 6.84 & 3.95 \\
\hline & 10 & 98.00 & 24.28 & 164.00 & 117.50 & 22.56 & 6.17 & 3.68 \\
\hline & 20 & 95.10 & 23.93 & 147.50 & 108.25 & 21.52 & 5.70 & 3.09 \\
\hline & 40 & 87.73 & 22.69 & 121.50 & 99.75 & 20.81 & 4.88 & 2.80 \\
\hline & 80 & 81.68 & 20.93 & 60.00 & 94.25 & 19.87 & 4.37 & 2.39 \\
\hline & 100 & 69.73 & 18.81 & 42.25 & 85.75 & 19.00 & 3.18 & 1.84 \\
\hline \multirow{6}{*}{70} & Zero & 105.33 & 25.08 & 206.75 & 134.25 & 24.85 & 7.51 & 4.10 \\
\hline & 10 & 101.35 & 24.69 & 191.50 & 129.00 & 23.73 & 7.24 & 3.89 \\
\hline & 20 & 96.05 & 24.19 & 163.75 & 118.75 & 22.87 & 6.85 & 3.55 \\
\hline & 40 & 91.83 & 23.73 & 115.50 & 110.25 & 22.39 & 6.18 & 3.25 \\
\hline & 80 & 86.53 & 23.03 & 91.75 & 104.50 & 21.31 & 5.59 & 2.87 \\
\hline & 100 & 77.55 & 20.33 & 65.00 & 94.25 & 20.88 & 4.46 & 2.17 \\
\hline \multirow{6}{*}{90} & Zero & 107.98 & 25.57 & 218.50 & 138.25 & 25.57 & 7.88 & 4.21 \\
\hline & 10 & 104.73 & 25.15 & 204.50 & 131.75 & 24.52 & 7.57 & 4.03 \\
\hline & 20 & 100.20 & 24.74 & 190.50 & 121.25 & 23.82 & 7.18 & 3.86 \\
\hline & 40 & 95.53 & 24.18 & 141.25 & 112.25 & 23.37 & 6.79 & 3.49 \\
\hline & 80 & 91.43 & 23.60 & 113.25 & 107.50 & 22.40 & 5.98 & 3.09 \\
\hline & 100 & 86.98 & 21.30 & 77.75 & 98.25 & 21.93 & 4.76 & 2.43 \\
\hline \multicolumn{2}{|c|}{ LSD $_{0.05}$} & 3.19 & 0.26 & 16.1 & NS & NS & 0.40 & 0.08 \\
\hline \multirow{7}{*}{50} & & \multicolumn{7}{|c|}{2016 season } \\
\hline & Zero & 94.80 & 24.24 & 187.75 & 124.50 & 23.58 & 6.55 & 3.84 \\
\hline & 10 & 91.33 & 23.83 & 162.25 & 118.75 & 22.44 & 5.87 & 3.57 \\
\hline & 20 & 87.95 & 23.38 & 145.25 & 109.50 & 21.43 & 5.39 & 2.99 \\
\hline & 40 & 80.53 & 22.18 & 95.25 & 101.00 & 20.71 & 4.83 & 2.69 \\
\hline & 80 & 75.10 & 20.50 & 58.50 & 95.75 & 19.77 & 4.07 & 2.30 \\
\hline & 100 & 60.35 & 18.35 & 36.00 & 88.00 & 18.91 & 2.96 & 1.71 \\
\hline \multirow{6}{*}{70} & Zero & 98.23 & 24.51 & 203.50 & 136.50 & 24.75 & 7.16 & 4.03 \\
\hline & 10 & 93.88 & 24.16 & 189.00 & 130.75 & 23.62 & 6.89 & 3.81 \\
\hline & 20 & 88.73 & 23.69 & 162.25 & 120.00 & 22.75 & 6.52 & 3.46 \\
\hline & 40 & 84.45 & 23.19 & 114.00 & 112.50 & 22.29 & 5.86 & 3.16 \\
\hline & 80 & 79.53 & 22.51 & 90.00 & 106.75 & 21.20 & 5.27 & 2.78 \\
\hline & 100 & 69.85 & 19.78 & 46.75 & 97.50 & 20.77 & 4.13 & 2.10 \\
\hline \multirow{6}{*}{90} & Zero & 102.18 & 24.77 & 216.25 & 140.00 & 25.47 & 7.56 & 4.15 \\
\hline & 10 & 98.43 & 24.45 & 202.50 & 133.50 & 24.41 & 7.32 & 3.94 \\
\hline & 20 & 94.05 & 24.00 & 188.25 & 123.50 & 23.72 & 6.96 & 3.77 \\
\hline & 40 & 88.78 & 23.50 & 139.25 & 114.50 & 23.26 & 6.47 & 3.41 \\
\hline & 80 & 84.40 & 22.98 & 111.75 & 109.50 & 22.28 & 5.66 & 2.99 \\
\hline & 100 & 80.20 & 20.88 & 76.00 & 100.00 & 21.83 & 4.54 & 2.34 \\
\hline \multicolumn{2}{|c|}{ LSD $_{0.05}$} & NS & NS & NS & $\mathbf{N S}$ & NS & NS & 0.20 \\
\hline
\end{tabular}

(18.81 and $18.35 \mathrm{~cm}),(42.25$ and 36.00$),(85.75$ and 88.00$),(19.00$ and $18.91 \mathrm{~g}),(3.18$ and 2.96 ton $\left.\mathrm{fed}^{-1}\right),\left(1.84\right.$ and 1.71 ton $\left.\mathrm{fed}^{-1}\right)$ in the same order of the tested parameters, respectively obtained from adding $50 \mathrm{~kg} \mathrm{~N} /$ fed. under natural infestation of (Cyperus difformis L) (about 100 plant $/ \mathrm{m}^{2}$ ). Similar results were obtained by Abou- khalifa et al., (2005) and Abdalla and Abou-Khalifa (2012).

\subsection{Prediction of rice grain yield losses/ fed} due to Cyperus difformis L. competition

Data in Table (12) and Fig. (1 and 2) Showed that increasing (Cyperus difformis L.) densities caused a significant reduction in grain yield (ton $\mathrm{fed}^{-1}$ ). also, it was clear that the suitable mathematical model which filled for prediction rice grain yield (ton $\mathrm{fed}^{-1}$ ) losses was 
Table (12): Effect of interaction between $\mathrm{N}$ - fertilizer rates and small-flower umbrella, (Cyperus difformis $\mathbf{L}$.) densities on observed and predicted yield and yield losses of broadcast rice in 2015 and 2016 seasons.

\begin{tabular}{|c|c|c|c|c|c|c|c|}
\hline \multirow{2}{*}{$\begin{array}{c}\text { Fertilizer } \\
\text { nitrogen } \\
\text { rates } \\
\left(\mathrm{kg} \mathrm{fed}^{-1}\right)\end{array}$} & \multirow{2}{*}{$\begin{array}{c}\text { Cyperus } \\
\text { difformis } \\
\text { densities } \\
\text { plant } \mathbf{m}^{-2}\end{array}$} & \multicolumn{3}{|c|}{2015 season } & \multicolumn{3}{|c|}{2016 season } \\
\hline & & $\begin{array}{c}\text { Observed } \\
\text { grain yield } \\
\left(\text { ton fed }^{-1}\right)\end{array}$ & 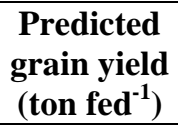 & $\begin{array}{c}\% \\
\text { Yield } \\
\text { losses }\end{array}$ & $\begin{array}{c}\text { Observed } \\
\text { grain yield } \\
\left(\text { ton } \text { fed }^{-1}\right)\end{array}$ & $\begin{array}{c}\text { Predicted } \\
\text { grain yield } \\
\left(\text { ton } \text { fed }^{-1}\right)\end{array}$ & $\begin{array}{c}\% \\
\text { Yield } \\
\text { losses }\end{array}$ \\
\hline \multirow{5}{*}{50} & Zero & 3.95 & 3.96 & 0 & 3.84 & 3.86 & 0.00 \\
\hline & 10 & 3.68 & 3.58 & 6.83 & 3.57 & 3.47 & 7.03 \\
\hline & 20 & 3.09 & 3.25 & 21.77 & 2.99 & 3.14 & 22.14 \\
\hline & 40 & 2.8 & 2.77 & 29.11 & 2.69 & 2.66 & 29.95 \\
\hline & 80 & 2.39 & 2.53 & 39.49 & 2.3 & 2.42 & 40.10 \\
\hline \multirow{5}{*}{70} & Zero & 4.1 & 4.11 & 0 & 4.03 & 4.04 & 0.00 \\
\hline & 10 & 3.89 & 3.86 & 5.12 & 3.81 & 3.77 & 5.46 \\
\hline & 20 & 3.55 & 3.66 & 13.42 & 3.46 & 3.53 & 14.14 \\
\hline & 40 & 3.25 & 3.36 & 20.73 & 3.16 & 3.18 & 21.59 \\
\hline & 80 & 2.87 & 3.25 & 30 & 2.78 & 2.97 & 31.02 \\
\hline \multirow{5}{*}{90} & Zero & 4.21 & 4.23 & 0 & 4.15 & 4.15 & 0.00 \\
\hline & 10 & 4.03 & 4.02 & 4.28 & 3.94 & 3.94 & 5.06 \\
\hline & 20 & 3.86 & 3.84 & 8.31 & 3.77 & 3.75 & 9.16 \\
\hline & 40 & 3.49 & 3.53 & 17.1 & 3.41 & 3.43 & 17.83 \\
\hline & 80 & 3.09 & 3.15 & 26.6 & 2.99 & 3.03 & 27.95 \\
\hline \multicolumn{2}{|c|}{$\mathbf{L S D}_{0.05}$} & 0.08 & - & - & 0.20 & - & - \\
\hline
\end{tabular}

2015

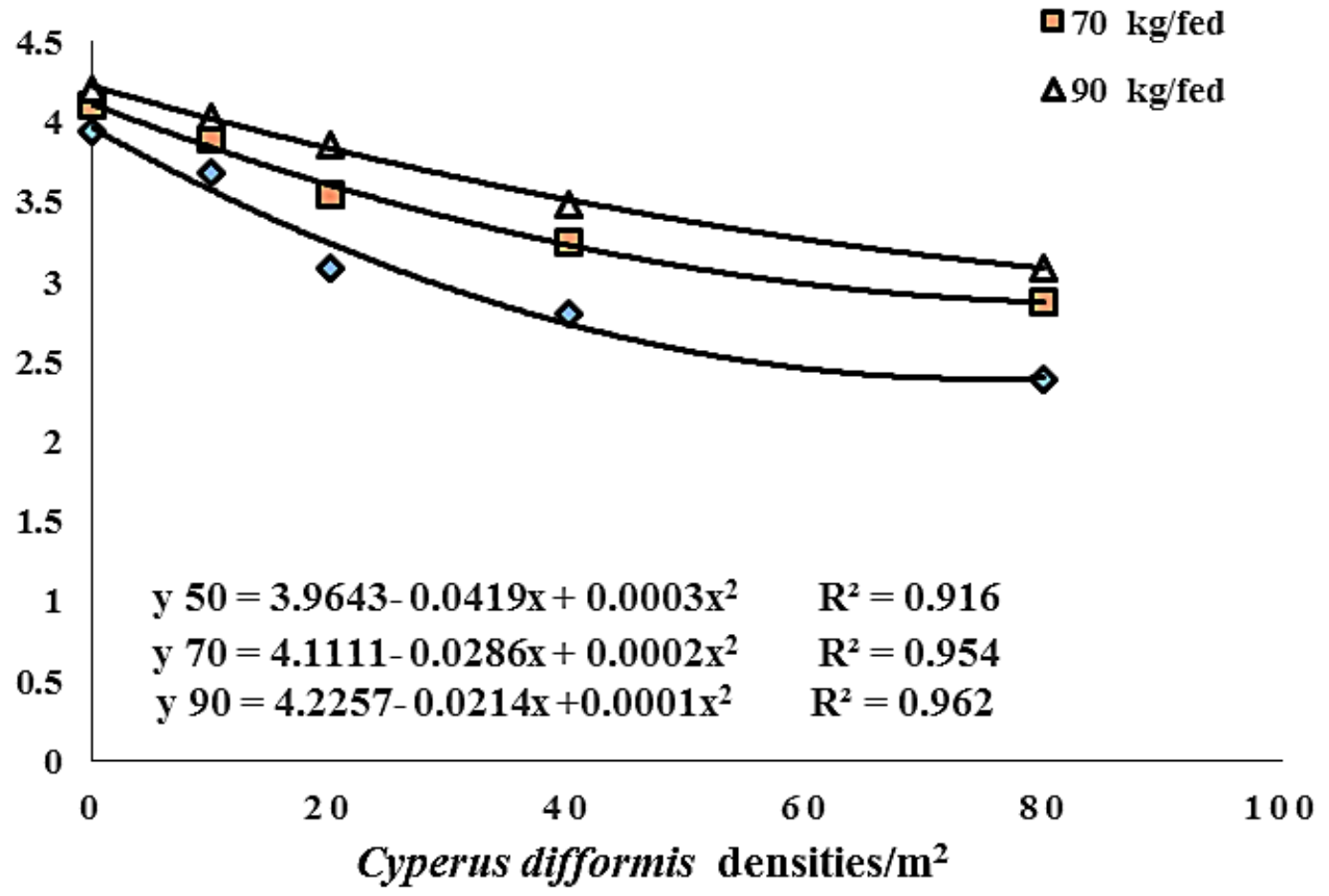

$\diamond 50 \mathrm{~kg} / \mathrm{fed}$ $\square 70 \mathrm{~kg} / \mathrm{fed}$

$\Delta 90 \mathrm{~kg} / \mathrm{fed}$

Fig. (1): Relationship between small-flower umbrella, Cyperus difformis, L. densities plants $\mathbf{m}^{-2}$ and rice grain yield (ton fed ${ }^{-1}$ ) under three nitrogen fertilizer rates 50,70 and $90 \mathrm{~kg}$ $\mathrm{N}$ fed $^{-1}$ in 2015 season. 


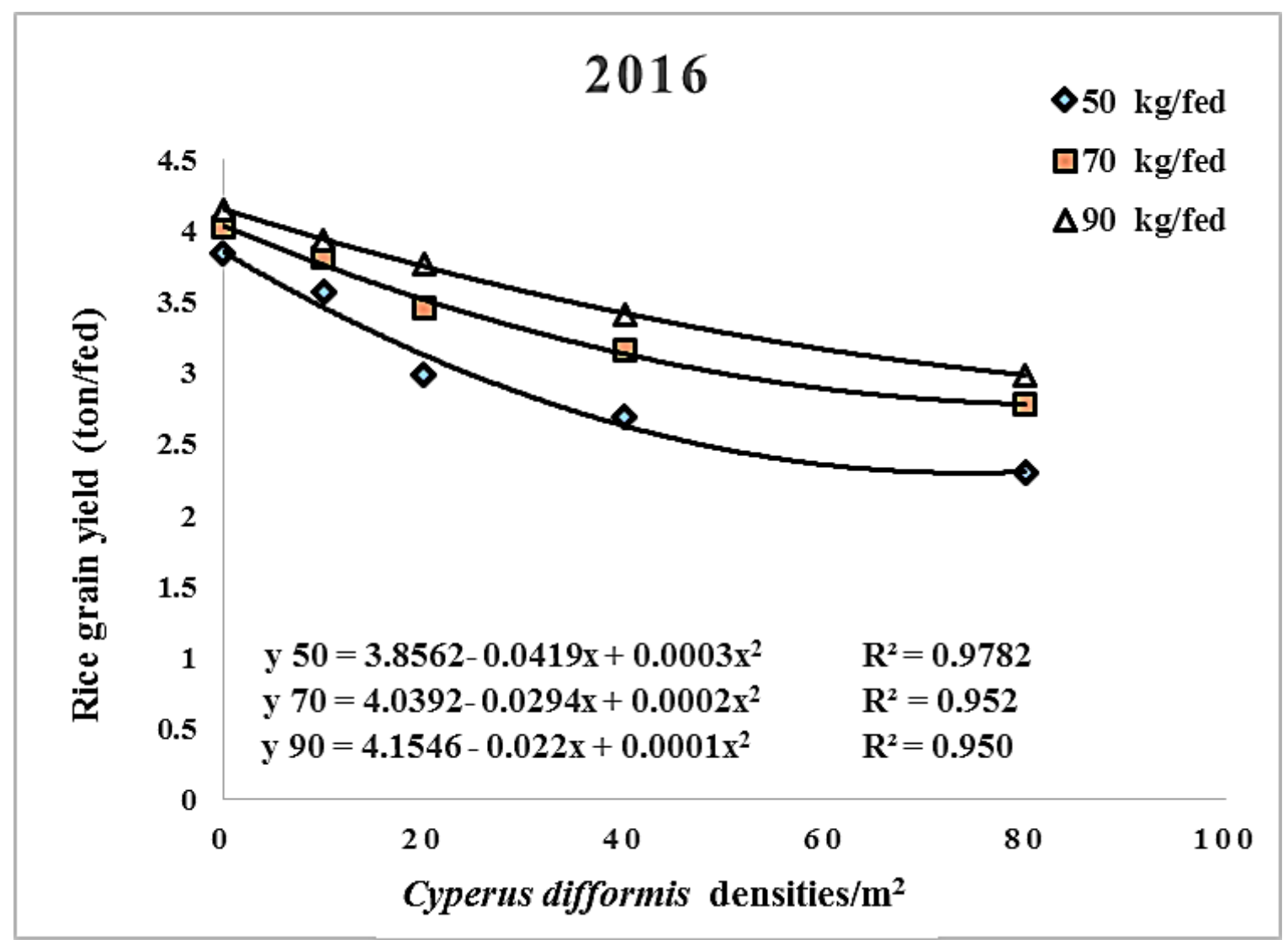

Fig.(2): Relationship between small-flower umbrella, Cyperus difformis L. dinisities plants $\mathrm{m}^{-2}$ and rice grain yield (ton/ fed.) under three nitrogen fertilizer rats $\mathbf{5 0 , 7 0}$ and 90

a quadratic function because the correlation coefficient $\left(\mathrm{R}^{2}\right)$ was greater than other studied models and standard estimate error (SE) were smaller than those of the other studied where polynomial models: $\hat{Y}=3.9643-0.0419 \mathrm{x}+$ $0.0003 \mathrm{x}^{2} \mathrm{R}^{2}=0.916, \quad \hat{\mathrm{Y}}=4.1111-0.0286 \mathrm{x}+$ $0.0002 \mathrm{x}^{2} \quad \mathrm{R}^{2}=0.954$ and $\mathrm{Y}=4.2257-0.0214 \mathrm{x}$ $+0.0001 \mathrm{x}^{2} \mathrm{R}^{2}=0.962$ due to the increasing Cyperus difformis L. densities from zero to 80 plants $\mathrm{m}^{-2}$ under $\mathrm{N}_{50}, \mathrm{~N}_{70}$ and $\mathrm{N}_{90}$, respectively in the first season and $\hat{\mathrm{Y}}=3.856-0.0419 \mathrm{x}+$ $0.0003 \mathrm{x}^{2} \quad \mathrm{R}^{2}=0.9782, \hat{\mathrm{Y}}=4.0392-0.0294 \mathrm{x}$ $+0.0002 \mathrm{x}^{2} \quad \mathrm{R}^{2}=0.952$ and $\hat{Y}=4.1546-$ $0.022 \mathrm{x}+0.0001 \mathrm{x}^{2} \quad \mathrm{R}^{2}=0.950$ under $\mathrm{N}_{50}, \mathrm{~N}_{70}$ and $\mathrm{N}_{90}$, respectively in the second season. Also, data showed that rice yield losses \% was increased by increasing nitrogen fertilizer levels from $\mathrm{N}_{50}$ to $\mathrm{N}_{90}$ and Cyperus difformis L. density from zero up to 80 Cyperus difformis L. plants $\mathrm{m}^{-2}$ in both seasons. It is clearly indicated from the Fig. (1) Rice crop don't compete at higher levels of nitrogen fertilizer and Cyperus difformis L. densities and there is a drastic decline in grain yield.

3.5.Correlation between all studied characters and rice grain yield

Data presented in Table (13) indicated that dry weight (g) small-flower umbrella (Cyperus difformis L.) plants were negatively and highly significantly correlated with plant height,panicle length, number of panicle $\mathrm{m}^{-2}$, number of full grain panicle ${ }^{-1}$, 1000-grain weight, straw yield and grain yield (ton $\mathrm{fed}^{-1}$ ) in both seasons. While, grain yield (ton $\mathrm{fed}^{-1}$ ) was positively and highly significantly correlated with plant height, panicle length, number of panicle $\mathrm{m}^{-2}$, number of full grain panicle ${ }^{-1}, 1000$-grain weight and straw yield (ton $\mathrm{fed}^{-1}$ ) in both seasons. Suggesting that rice grain yield can be affected strongly by (Cyperus difformis L.) competition, and need suitable control program for this weed species to increase rice productivity per unit area broadcasted planting method. 
Table (13): Correlation coefficient between morphological yield and its components traits in 2015 and 2016 seasons.

\begin{tabular}{|c|c|c|c|c|c|c|c|c|}
\hline Characters & $\begin{array}{c}\text { Fresh } \\
\text { weight } \\
\text { (g) }\end{array}$ & $\begin{array}{c}\text { plant } \\
\text { height } \\
\text { (cm) }\end{array}$ & $\begin{array}{c}\text { Panicle } \\
\text { length } \\
\text { (cm) }\end{array}$ & $\begin{array}{c}\text { No. } \\
\text { panicle } \\
\mathbf{m}^{-2}\end{array}$ & $\begin{array}{c}\text { No. of } \\
\text { full grain } \\
\text { panicle }^{-1}\end{array}$ & \begin{tabular}{|c|} 
1000- \\
grain \\
weight \\
(g)
\end{tabular} & $\begin{array}{c}\text { Straw } \\
\text { yield } \\
\left.\text { (ton fed }^{-1}\right)\end{array}$ & $\mid \begin{array}{c}\text { Grain } \\
\text { yield } \\
{\left.\text { (ton } \text { fed }^{-1}\right)}^{-1}\end{array}$ \\
\hline \multicolumn{9}{|c|}{2015 Season } \\
\hline Dry weight $(\mathrm{g})$ & $0.989 * *$ & $-0.796 * *$ & $-0.840 * *$ & $-0.835 * *$ & $-0779 * *$ & $-0.606 * *$ & $-0.848 * *$ & $-0.773 * *$ \\
\hline plant height $(\mathrm{cm})$ & & & $0.936 * *$ & $0.954 * *$ & $0.943 * *$ & $0.880 * *$ & $0.933 * *$ & $0.941 * *$ \\
\hline Panicle length $(\mathrm{cm})$ & & & & $0.919 * *$ & $0.908 * *$ & $0.789 * *$ & $0.961 * *$ & $0.937 * *$ \\
\hline No. panicle $\mathrm{m}^{-2}$ & & & & & $0.960 * *$ & $0.870 * *$ & $0.951 * *$ & $0.949 * *$ \\
\hline $\begin{array}{l}\text { No. of full grain } \\
\text { panicle }^{-1}\end{array}$ & & & & & & $0.879 * *$ & $0.947 * *$ & $0.960 * *$ \\
\hline $\begin{array}{l}\text { 1000-grain weight } \\
(\mathrm{g})\end{array}$ & & & & & & & $0.802 * *$ & $0.903 * *$ \\
\hline Straw yield (ton/fed) & & & & & & & & $0.946 * *$ \\
\hline \multicolumn{9}{|c|}{ 2016 Season } \\
\hline Dry weight $(\mathrm{g})$ & $0.988 * *$ & $-0.779 * *$ & $-0.823 * *$ & $-0.838 * *$ & $-0.771 * *$ & $-0.605 * *$ & $-0.836 * *$ & $-0.790 * *$ \\
\hline plant height $(\mathrm{cm})$ & & & $0.952 * *$ & $0.937 * *$ & $0.937 * *$ & $0.929 * *$ & $0.878 * *$ & $0.937 * *$ \\
\hline Panicle length $(\mathrm{cm})$ & & & & $0.912 * *$ & $0.913 * *$ & $0.870 * *$ & $0.888 * *$ & $0.840 * *$ \\
\hline No. panicle $\mathrm{m}^{-2}$ & & & & & $0.955 * *$ & $0.869 * *$ & $0.937 * *$ & $0.943 * *$ \\
\hline $\begin{array}{l}\text { No. of full grain } \\
\text { panicle }\end{array}$ & & & & & & $0.924 * *$ & $0.909 * *$ & $0.961 * *$ \\
\hline $\begin{array}{l}\text { 1000-grain weight } \\
\text { (g) }\end{array}$ & & & & & & & $0.797 * *$ & $0.915 * *$ \\
\hline Straw yield (ton/fed) & & & & & & & & $0.916^{* *}$ \\
\hline
\end{tabular}

\section{REFERENCES}

Abdalla A. and Abou-Khalifa A.A. (2012). Evaluation of some rice varieties under different nitrogen levels. Advances in Appl. Sci. Res., 3(2):1144-1149.

Abou Khalifa A.A., El-Rewainy I.O., AbdelWahab A.E. and Salem A.K.M. (2005). Effect of seedling rates and nitrogen levels on phenology, growth and yield of Sakha 101 and Sakha 102 rice cultivars under broadcast-seeded rate. Egypt. J. Agric. Res. 83(5B): 435-445.

A.O.A.C. (1990). Official methods of analysis. $15^{\text {th }}$ Ed., Association of Official Analytical Chemists, Inc., Virginia, USA, pp: 770 - 771.

Belder P., Spiertz J.H.J. and Bouman B.A.M. (2005). Nitrogen economy and water productivity of lowland rice under water irrigation. Field Crop Res., 93: 169-185.

Black C.A. (1965). Method of soil analysis. Amer. Agron. Inc .Madeson, Wisconsin USA.131-137

El-Dalil M. A.E., Abd-El Ghany Eman K.E., Abu El-Ezz, A.Fouad (2017). Yield, Yield Components and Grain Quality of Giza 179
Egyptian Rice Cultivar as Affected by Seeding Rates and Nitrogen Levels using Broadcasting Planting Method. Alexandria Sci. Exchange J., 38, (4): 707 - 717.

Estorninos L.E., Geoly D.R. and Gbur E.E. (2005). Rice and red rice interference. Rice response to population densities of three red rice ecotypes. Weed Science, 53: 683-689.

Gomez K.A and Gomez A.A. (1984). Chisquare test. Pages 458 - 477 in Statistical Procedures for Agricultural Research. John Wiley and Sons. Toronto.

Haefel S.M., Naklang K.and Harnpichitvitaya D. (2006). Factor affecting rice yield and fertilizer response in rain fed lowlands of northeast Thailand. Field Crop Res., 98 : 39- 51.

Jackson, M.L. (1973). Soil chemical analysis. Printice Hall Inc., Englewood Cliffs, New Jersey, U.S.A.

Jain G., Singh C.S., Singh A. K., Singh S.K. and Puran A.N. (2018). Effect of nitrogen levels and weed management practices on growth, yield and uptake of rice under aerobic conditions. J.Pharmacogn. and Phytochem.; SP1: 381-385. 
Kumar V., Bellinder R. R., R. K., Gupta R. K. Malik and Brainard D. C. (2008). Irrigated rice cultivars in Latin America. Agronomy Jounal, 89: 516- 521.

Maity S.K. and Mukerjee P.K.(2008). Integrated weed management in dry-seeded rice (Oryza sativa L.). Indian J. Agron., 53(2): 116-120.

Revathi, A. (2009). Establishment techniques and weed management practices in puddle lowland rice. M.Sc. (Ag.) Thesis .Tamil Nadu Agricultural University, Coimbatore, Tamil Nadu, India

Seema K. M. and Tohi D. M. (2010). Effect of nitrogen and management on nutrient uptake by weeds under direct seeded aerobic rice. Int`l quart. J. life Sci., 9 (2): $535-537$.

Sheeja, J., Singh S.K. and Singh C.M. (2013). Influence of methods and stand establishment on growth and yield of rice. Oryza, 28: 45-48.

Singh D. K., Pandey P. C., Riyanker P., Qureshi A. and Gupta S. (2015). Nitrogen management strategies for direct seeded aerobic rice (Oryza sativa L.) grown in mollisols of Uttarakhand (India), Int ${ }^{`}$. J. Appl. Pure Sci. Agric., 7 (1): 130 - 138.
Singh G., Singh R.G., Singh O.P., Mehta R.K. , Kumar V.and Singh P.P. (2005). Effect of weed- management practices on direct seeded rice (Oryza sativa L.) under puddle lowlands. Indian J. Agron., 50 (1): 35 - 37.

Singh, P.; R. Singh; K.N. Singh; P. Sofi and F.A. Bahar (2009). Efficacy of herbicides and mulching for controlling weeds in transplanted rice. Indian Journal of Agronomy, 46 (4): 332-334.

Singh S., Ladha J.K. , Gupta R.K., Bhushan L.and Rao A.N. (2007). Weed management in aerobic rice systems under varying establishment methods. Crop protect., 27(35): 660-671.

Singh V., Singh H. and Raghubanshi A. S. (2017).Effect of $\mathrm{N}$ application on emergence and growth of weeds associated with rice. Trop. Ecol., 58(4): 807-822.

Snedecor G.W. and Cochran W.G. (1989). Statistical Methods. $6^{\text {th }}$ Ed., Iowa State Univ. Press., Ames., USA: 325-330.

Tkachuk R. (1966). Note on the nitrogen to protein conversion factor for wheat flour. Cereals Chem. 43 : 223-225.

Zimdahl, R.L. (2004). Weed Crop Competition. A review. Blackwell Publishing, pp:220. 


\title{
تاثير معدلات السماد النيتروجيني ومنافسة حشيشة العجيرة علي امتصاص العناصر الغدائية وانتاجية الارز البدار
}

\author{
ابراهيم السيد سليمان ، محمد عماد زكي قنيبر و اسامة ماهر مبارك
}

$$
\text { المعمل المركزي لبحوث الحشائش - مركز البحوث الزر اعية ـ الجيزة ـ- مصر }
$$

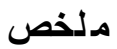 \\ أجريت تجربتان حقليتان بمحطة البحوث الزراعية بالجميزة ، محافظة الغربية ، خلال موسمي الزراعة الصيفي}

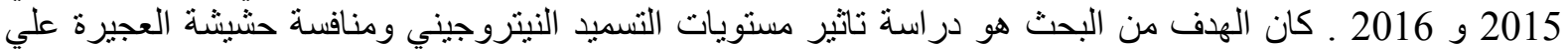

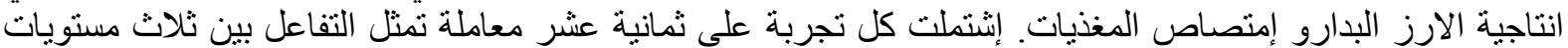

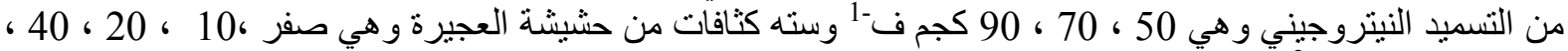

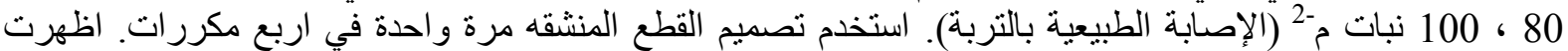

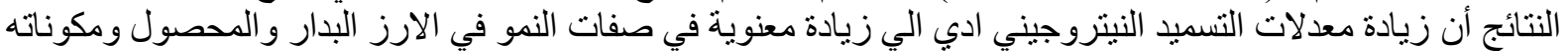

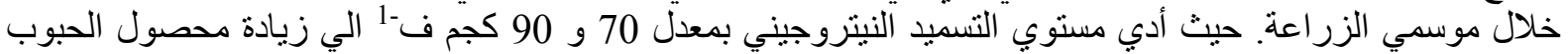

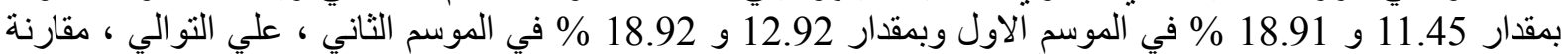

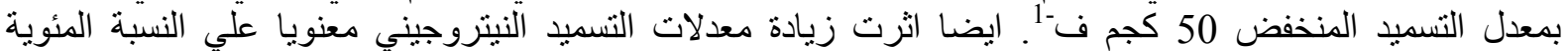

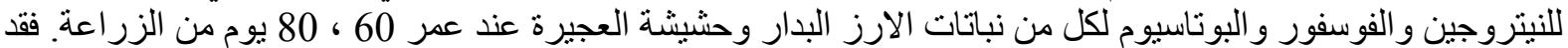

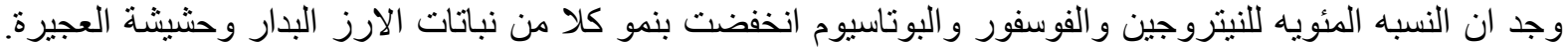

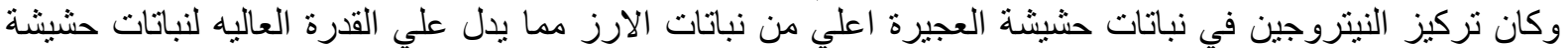

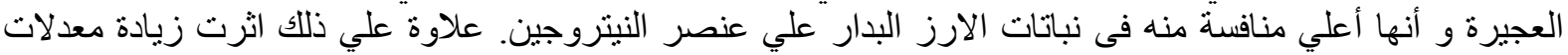

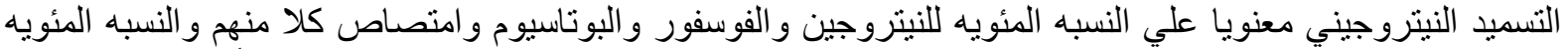

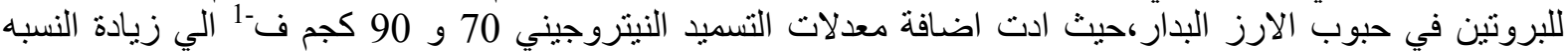

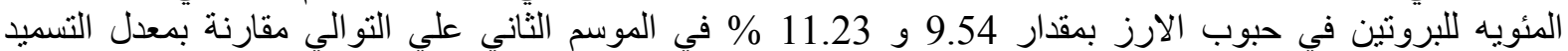

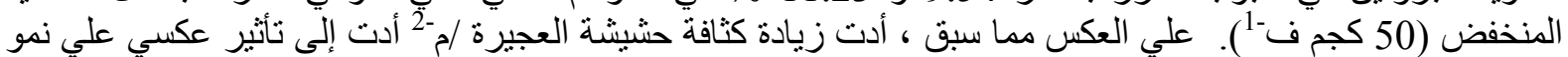

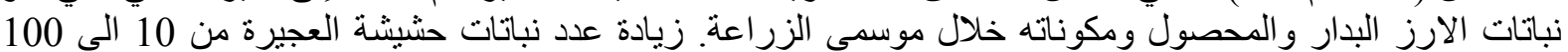

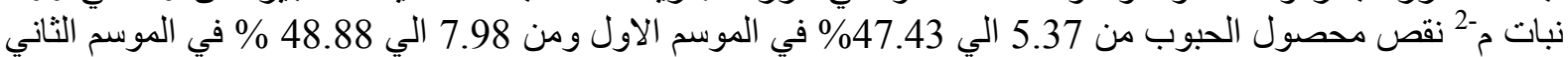

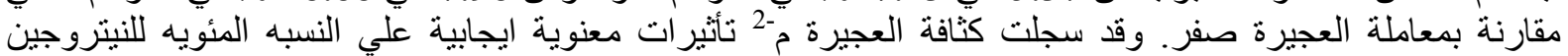

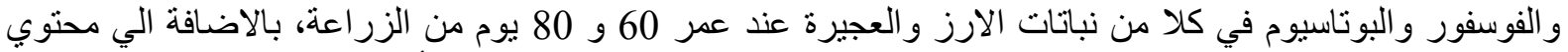

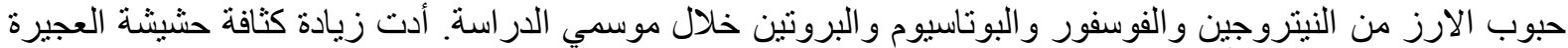

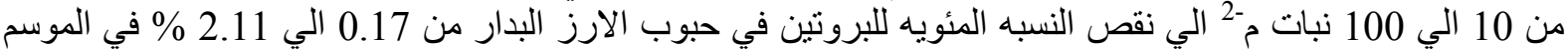

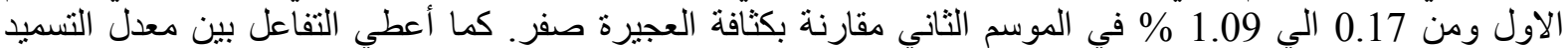

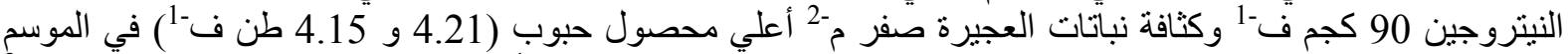

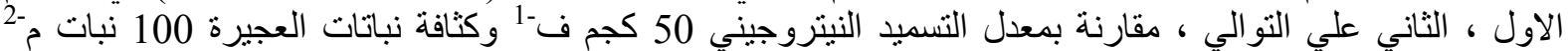

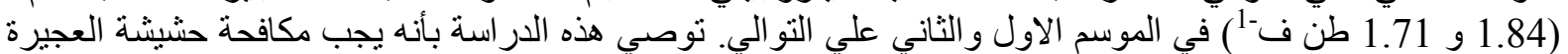

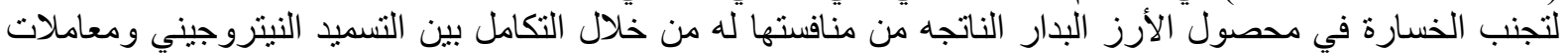

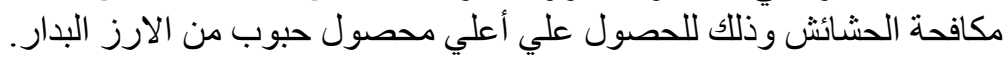

